The American Journal of Political Science Law and Criminology

(ISSN - 2693-0803)

VOLUME 04 ISSUE 01 Pages: 14-18

SJIF IMPACT FACTOR (2020: 5. 453) (2021: 5. 952)

OCLC - 1176274523 METADATA IF - 7.659

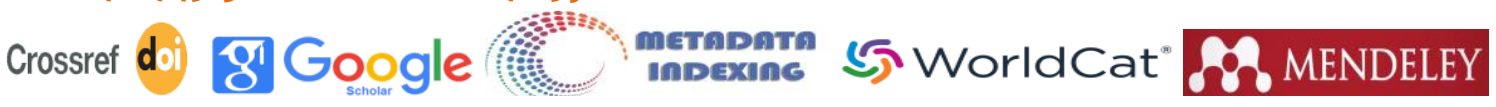

Research Article

\title{
REFORMS FOR ENHANCING THE ROLE OF POLITICAL PARTIES
}

Submission Date: January 09, 2022, Accepted Date: January 20, 2022,

Published Date: January 30, 2022

Crossref doi: https://doi.org/10.37547/tajpslc/Volume04Issue01-03

Journal Website: https://theamericanjou rnals.com/index.php/ta jpslc

Copyright: Original content from this work may be used under the terms of the creative commons attributes 4.0 licence.

Ikhtiyor Bekov

Associate Professor of Tashkent state university of Law, Uzbekistan

Makhbuba Saidboyeva

Lecturer of Tajik state university of law, business and politics, Uzbekistan

\section{ABSTRACT}

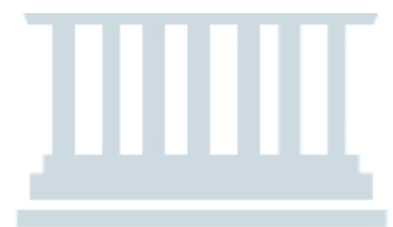

This article explores the tasks of increasing the role of political parties, Legislative chamber factions and party groups of local Kengashes in public life in the Republic of Uzbekistan, as well as, in the direction of the importance of reforms in the political sphere of the Republic of Uzbekistan over the past three years.

\section{KEYWORDS}

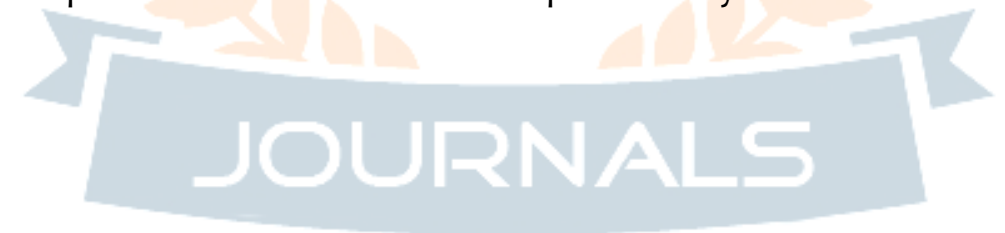

Political party, faction, party groups, elections.

\section{INTRODUCTION}

In multi-party democracies, the law regulates the relationship between political parties and other institutions of the political system, determines the forms of their participation in the formation and activities of various state bodies, and the nature of their relations with other public organizations.
The activities of the parties in this regard are based on the principles of their separate existence, independence, and non-interference in each other's affairs. It should be noted that these principles are enshrined in a number of international instruments 
The American Journal of Political Science Law and Criminology (ISSN - 2693-0803)

VOLUME 04 ISSUE 01 Pages: 14-18

SJIF IMPACT FACTOR (2020: 5 - 453) (2021: 5. 952)

OCLC - 1176274523 METADATA IF - 7.659

relating to the relationship between political parties and the state.

In particular, in a document adopted by the Organization for Security and Co-operation in Europe (OSCE) at the 1990 Copenhagen Conference on Human Criteria, member states stated that: "Strict boundaries between the state and political parties", that is, the characteristics of political parties that do not merge with the state. [1].

The level of development of political pluralism and multiparty system in the constitutional system allows us to imagine the socio-political forces that are active in the political system as a carrier of different ideologies in the struggle for power. Such a force, representing and embodying different political ideas and views, can be parties that must act on the basis of equality before the law and only the law. [2].

In particular, according to $\mathrm{H}$. Kelsen, the basis of modern democracy is formed by parties, "... the higher their importance, the more fully the democratic principle is realized." According to him, the constitutional and legal strengthening of political parties "... will allow to democratize the process of forming a common will in this area." [3].

Based on the tasks set out in the Action Strategy for the five priority areas of development of the Republic of Uzbekistan for 2017-2021, a number of measures aimed at further democratization and modernization of public administration, ensuring reliable protection of civil rights and freedoms, including the gradual formation of a strong civil society fundamental and large-scale reforms are underway.

In particular, reforms to improve the institutions of civil society and the legal framework for their activities are being carried out gradually.
All legal grounds have been created for political parties to implement their ideas and programs, to actively participate in elections on the basis of equality, openness and impartiality, to form their factions and party groups in parliament and local representative bodies, and to take an active part in political and social life.

On July 12, 2017, the President of the Republic of Uzbekistan Sh. Mirziyoyev held a video conference with representatives of the chambers of the Oliy Majlis, political parties and the Ecological Movement of Uzbekistan. This is the first time that such a meeting has been held in our country. The meeting analyzed the activities of political parties in the past in the form of dialogue, in a critical spirit, and identified the important tasks facing them in further deepening the reforms.

Over the past three years, historical changes have taken place in the formation of political parties, which are important institutions of civil society, and in the formation of their representative bodies of state power, and in increasing their participation and role in their activities. We can consider them in the following examples:

Firstly, in order to radically improve the activities of factions of political parties in the Legislative Chamber of the Oliy Majlis of the Republic of Uzbekistan, the positions of executive secretaries of political party factions were introduced in the Legislative Chamber. This serves as a "bridge" between the Legislative Chamber and political parties.

Secondly, the positions of executive secretaries of party groups were introduced in Local Councils. The executive secretaries of the Party Councils organize the activities of the deputy groups of their party, the protection of the clear views of the group in the local executive power. Develops a common position of the 
The American Journal of Political Science Law and Criminology (ISSN - 2693-0803)

VOLUME 04 ISSUE 01 Pages: 14-18

SJIF IMPACT FACTOR (2020: 5 - 453) (2021: 5. 952)

OCLC - 1176274523 METADATA IF - 7.659

group on the issues under consideration, helps to coordinate the activities of the group members, plays an important role in taking into account the views of the party and the interests of the electorate in the development of sectoral programs and discussion of local decisions. [4].

Thirdly, a new system has been established to establish effective parliamentary and parliamentary control over the activities of party factions and deputy groups in the executive branch. According to it, the center will consider the issues of defining the scope of public administration bodies controlled by factions and party groups in the regions, hearing their reports and information at the relevant faction meetings, identifying shortcomings and making substantiated information and suggestions on the incompetence of leaders.

Fourthly, according to the Law of the Republic of Uzbekistan No. ORQ-527 of March 5, 2019, a candidate for the Cabinet of Ministers will be considered and approved by the Legislative Chamber of the Oliy Majlis of the Republic of Uzbekistan after initial consideration by factions of political parties in the Legislative Chamber. The introduction of this practice will further increase the role and capacity of factions of political parties in the formation of the government and its members.

Fifthly, according to the amendment to the Law of the Republic of Uzbekistan No. ZRU-476 of April 18, 2018, party groups in the Jogorku Kenesh of the Republic of Karakalpakstan, the Councils of People's Deputies will be formed if at least three deputies elected to these Councils unite.

Prior to that, this requirement was five for the Jogorku Kenesh of the Republic of Karakalpakstan, regional, Tashkent city and city (regional center) Councils of
People's Deputies. For district councils, however, there was no clear requirement and no legal basis for the mechanism. Previous demands and uncertainties led not only to difficulties in the activities of party groups in local councils, but also to various misunderstandings. For example, if two deputies were elected to the relevant district council from a single political party, the question of whether they could form a party group remained open.

Sixthly, according to the amendment to the Law of the Republic of Uzbekistan No. ZRU-476 of April 18, 2018, was given the right to submit a conclusion about unsatisfactory activities of district (city) khokims, as well as officials of relevant local executive bodies to the Jogorku Kenesh of the Republic of Karakalpakstan, regional or Tashkent city khokims.

Seventhly, in accordance with the amendments introduced by the Law of the Republic of Uzbekistan No. ORQ-476 of April 18, 2018, the institution of a representative of the member of the Legislative Chamber of the Oliy Majlis of the Republic of Uzbekistan was introduced. According to it, a political party, in agreement with a deputy of the Legislative Chamber of the Oliy Majlis of the Republic of Uzbekistan, will appoint a public representative from among the employees of the territorial branch of the party in the relevant constituency.

Representative of the deputy of the Legislative Chamber of the Oliy Majlis of the Republic of Uzbekistan:

Assists the deputy in establishing regular contacts with his constituents in the constituency;

Registers appeals of individuals and legal entities addressed to the deputy in the constituency and informs the deputy about it; 
The American Journal of Political Science Law and Criminology

(ISSN - 2693-0803)

VOLUME 04 ISSUE 01 Pages: 14-18

SJIF IMPACT FACTOR (2020: 5. 453) (2021: 5. 952)

OCLC - 1176274523 METADATA IF - 7.659

Crossref
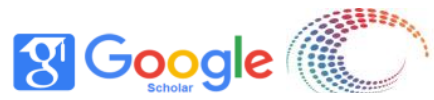

metapata

5) WorldCat"

Publisher: The USA Journals

Assists the deputy in receiving individuals and representatives of legal entities, as well as in organizing the deputy's meetings with voters;

Organizes work related to the exercise of the deputy's powers in the territory of the constituency on behalf of the deputy;

Perform other duties of the deputy in the exercise of his powers.

Eighthly, based on the proposals made by President Sh. Mirziyoyev at a video conference with representatives of the Oliy Majlis, political parties, and the Ecological Movement of Uzbekistan on July 12, 2017 [5], the practice of holding a meeting of political party leaders with the President once a year was established. A vivid example of this is the meeting of the President of the Republic of Uzbekistan Shavkat Mirziyoyev on August 22 with the leaders of political parties operating in our country[6]. The meeting was significant in that it provided an in-depth analysis of the activities of political parties in the light of the requirements of large-scale reforms in the country, as well as ideas and practical suggestions for improving their work and efficiency.

In addition, the amendments to the electoral legislation and the Electoral Code of the Republic of Uzbekistan introduced a number of benefits and opportunities for the participation of political parties in elections. We can consider them in the following examples:

The fact that only candidates were nominated by political parties in the upcoming elections to the representative bodies gave each party a great right and opportunity. Candidates for deputies to the Legislative Chamber of the Oliy Majlis in one hundred and fifty constituencies are nominated only by political parties (before the adoption of the Electoral Code, fifteen deputies of the Legislative Chamber were elected at the Conference of the Ecological Movement of Uzbekistan);

According to the current procedure, candidates for regional, district and city Kengashes of People's Deputies are nominated only by political parties (before the adoption of the Electoral Code, selfgoverning bodies also had the right to nominate candidates for district and city Kengashes);

When collecting signatures by political parties, voters were given the opportunity to sign in support of a number of parties. This will make it easier and more convenient for political parties to collect signatures in support of their participation in the elections;

Political parties are required to publish information on the financing of their participation in their elections on their official websites and in print within one month of the announcement of the election results. Previously, there was no such requirement in our legislation. The introduction of this provision will ensure that the electoral process, especially those related to its financing process, is conducted in an open and transparent manner;

It was stipulated that a political party could revoke its decision to nominate a person fifteen days before the election (previously this period was five days).

The above examples demonstrate the importance of the legal framework and the ongoing reforms aimed at increasing the role of political parties in the management of the state and society in a short period of time.

We believe that in order for political parties to have their place in the life of society, taking advantage of the 
The American Journal of Political Science Law and Criminology

(ISSN - 2693-0803)

VOLUME 04 ISSUE 01 Pages: 14-18

SJIF IMPACT FACTOR (2020: 5. 453) (2021: 5. 952)

OCLC - 1176274523 METADATA IF - 7.659

Crossref do

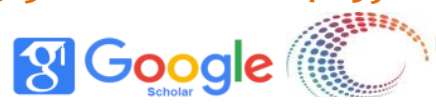
metapata 5 WorldCat

Publisher: The USA Journals

rights granted to them in the legislation, it is necessary to carry out the following tasks::

1. Political parties must constantly carry out the level of activity in the period of elections, throughout their activities. They must constantly establish their relations with voters on the basis of appropriate plans.

2. Recruitment of personnel loyal to the idea of the party to the management apparatus of political parties and the formation of candidates for deputies from among them.

3. To establish parliamentary and Deputy control over the executive body through political party factions in the Legislative Chamber of the Oliy Majlis and party groups in local councils, to express the interests of the country without taking full advantage of the legal opportunities given in this regard.

4. Increase their activity in social networks in order to further enhance the interaction of political parties with voters and citizens. The latest analysis shows that political parties are not so active in social networks. The number of their subscribers in social networks, they do not even make up five percent of their members.

\section{REFERENCES}

1. Declaration on the criteria for free and fair elections ( $\mathrm{pr}$ documents of the InterParliamentary Union). - M., 1994. - p. 9. [O критериях свободных и справедливых выборов (пр документам Межпарламентского Союза). M., 1994. - C.9.]

2. Avakyan S.A. Political pluralism and public associations in the Russian Federation: constitutional and legal framework. - M.: RUID, 1996.- S. 8 [Авакьян С.А. Политический плюрализм и общественные объединения в
Российской Федерации: конституционноправовые основы. - М.: РЮИД, 1996. - С. 8.]

3. Kelsen H. Vom Wessen und Wert der Demokratie. - Tubingen, 1926. - S. 19.

4. The executive secretaries are developing party groups) http://old.xdp.uz/oz/news/?ID=44756

5. Mirziyoev Sh. Our parliament should become a school of true democracy, the initiator and main implementer of reforms. http://uza.uz/oz/politics/parlamentimiz-a-i-iydemokratiya-maktabiga-aylanishi-islo-ot-12-072017

6. Political parties must become active participants in democratic processes.

7. http://uza.uz/oz/politics/siyesiy-partiyalardemokratik-zharayenlarning-faol-ishtirokch-22-082019

8. Беков, Ихтиёр. "The fraction of a political party is an important subject of the legislative process." Общество и инновации 2.6/S (2021): 292-301.

9. Алиева, Камола. "Гендер тенглигини таъминлаш бўйича мукаммал хуқуқий ислохотларнинг ўзи етарлими (европа иттифоқи тажрибасига назар)?." Общество и инновации 2.4/S (2021): 861-869.

10. Khoshim o'gli, Madiev Fakhriddin. "Constitutional Basis of Ensuring the Right to Privacy in the Age of Informatization." Middle European Scientific Bulletin 11 (2021).

11. Беков, Ихтиёр Рустамович. "СИЁСИЙ ПАРТИЯЛАРНИНГ ФРАКЦИЯЛАРИ-ПАРЛАМЕНТ НАЗОРАТИНИНГ МУХИМ СУБЪЕКТИ." ЖУРНАЛ ПРАВОВЫХ ИССЛЕДОВАНИЙ 6.12 (2021).

12. Bakhodirov, Javlon B. "ISSUES OF IMPROVING THE ACTIVITIES OF THE PROSECUTOR'S OFFICE IN THE REPUBLIC OF UZBEKISTAN." International Scientific and Current Research Conferences. 2021. 